\title{
Settlement of brachyuran megalopae in a South Carolina, USA, estuary
}

\author{
Jeanne M. Boylan ${ }^{1}$, Elizabeth L. Wenner ${ }^{2}$ \\ ${ }^{1}$ Grice Marine Biology Laboratory, College of Charleston, Charleston, South Carolina 29422-2559, USA \\ ${ }^{2}$ Marine Resources Research Institute, Box 12559, Charleston, South Carolina 29422-2559, USA
}

\begin{abstract}
Megalopae of 19 different taxa of brachyuran crabs were collected on passive collectors made from an artificial substrate at a single site within Charleston Harbor, South Carolina, in 1987-88. The blue crab Callinectes sapidus was the numerically dominant and most frequently collected species. Other numerically important taxa were mud crab Panopeus herbstii and fiddler crabs Uca spp. Settlement patterns were highly episodic, with approximately $42 \%$ of the total number of megalopae collected on a single sampling date. Major settlement peaks for C. sapidus megalopae occurred from August through October in both 1987 and 1988. Diel differences in abundance were apparent, with a significantly greater number of megalopae collected at night. Tidal range, wind speed, lunar phase, bottom water temperature, and bottom water salinity were correlated significantly with megalopal abundance. Megalopae of $C$. sapidus exhibited a semilunar pattern of settlement, with peak settlement occurring on waning phases of quarter moons. Juveniles constituted less than $0.3 \%$ of the total catch of early crab instars and megalopae of $C$. sapidus, suggesting that ingress into estuarine habitats occurs at the megalopal stage. Other portunids apparently recruit to Charleston Harbor at the juvenile stage.
\end{abstract}

\section{INTRODUCTION}

Meteorologic and hydrographic conditions are important regulators of recruitment and settlement of marine invertebrates (Roughgarden et al. 1988). The larvae of brachyuran decapod crustaceans that inhabit estuaries as adults may be retained within the estuary, as in the family Xanthidae, or flushed to the coastal ocean, where larval development of taxa such as Callinectes sapidus and $U_{c a}$ spp. takes place. Larval transport from offshore to estuarine habitats may be facilitated by behavioral adaptations of larvae coupled with wind-driven surface currents (Hester 1983, Johnson et al. 1984, Johnson 1985, Goodrich et al. 1989), on-shore deep residual currents (Sulkin \& Epifanio 1986), or internal waves (Shanks 1988). Maintenance of adult populations is accomplished by balancing larval export from the adult habitat with import of postlarvae or juveniles. Variations in adult abundance of decapods have been related to postlarval availability and settlement (Christmas \& van Devender 1981, Morgan et al. 1982, Phillips 1986).
Although physical processes that affect rates and timing of settlement are not very well understood for brachyurans, several studies have indicated a correlation between settlement of larvae and physical factors. Recent studies suggest a prominent role for intermittent wind-driven transport of surface waters in larval recruitment of blue crab (Hester 1983, Johnson 1985, Goodrich et al. 1989). Both wind direction and inner continental shelf circulation have been determined to be important factors affecting the ingress of blue crab larvae to the mouths of estuaries in the Middle Atlantic Bight, USA (Boicourt 1982). In addition, successful settlement of Cancer magister larvae along the coasts of California, Oregon, and Washington (USA) was found to be associated with wind stress, suggesting a wind-forced mechanism of larval recruitment (Johnson et al. 1986, Botsford \& Shenker 1988). Settlement in the grapsid crab Pachygrapsus crassipes was correlated with the period preceding maximum spring tides, possibly because transport was facilitated by internal waves (Shanks 1988).

A useful methodology in determining settlement rates of larval crabs and lobsters has been passive col- 
lectors which provide an artificial settlement substrate (Witham et al. 1968, Phillips 1972, Serfling \& Ford 1975, Little \& Milano 1980, Shanks 1983, Beninger et al. 1986, Phillips 1986, Olmi et al. 1990, van Montfrans et al. 1990). In the present study, we determined the patterns of postlarval (i.e. megalopal) settlement of Brachyura at a site in a South Carolina estuary over a 15 mo period and related settlement on an artificial substrate to temporal, physical, and meteorological factors. Little is known about these processes as they pertain to brachyuran postlarvae in South Carolina.

\section{STUDY SITE}

Sampling was conducted at a single site in Charleston Harbor (Fig. 1), a stratified estuary formed by the confluence of the Ashley, Wando, and Cooper Rivers. The 3 rivers comprise more than 26000 ha of marshlands and open water habitat (NOAA 1985). The Cooper River is the major source of freshwater inflow. Prior to 1985 waters from the Santee River were diverted into the Cooper River, resulting in distinct seasonal trends in freshwater discharge; however, after rediversion seasonal variability of freshwater inflow has been insignificant, although daily mean flow does fluctuate (Davis et al. 1990). Charleston Harbor has semidiurnal tides with a 1.8 to $2.0 \mathrm{~m}$ tidal range (Kjerfve et al. 1990). At the sampling site, the harbor is $3.3 \mathrm{~m}$ deep at mean low water (MLW) and theharbor bottom is predominately mud and sand (Mathews \& Shealy 1978).

\section{MATERIALS AND METHODS}

Collections of megalopae were made from July 29, 1987, through October 25, 1988. Day and night samples were taken consecutively once every $5 \mathrm{~d}$. During a period of peak ingress in September and October 1988, daily samples were taken. Collectors for the day treatment were deployed 1 h after sunrise and retrieved $1 \mathrm{~h}$ before sunset, whereas night collectors were placed in the water $1 \mathrm{~h}$ after sunset and picked up 1 h before sunrise.
Megalopae were collected on commercial 'hogshair' air conditioner filters $(38 \times 50 \times 1 \mathrm{~cm})$ that were suspended from a dock. Collection of megalopae was facilitated by their positive thigmotactic behavior at settlement. Three replicate sets of 2 collectors each were deployed for each day and night treatment. The horizontal distance between replicates was approximately $1 \mathrm{~m}$. The 2 collectors in each set were suspended from the dock by a harness which oriented them vertically in the water column. Each of the 3 upper collectors was attached $1 \mathrm{~m}$ below mean low water and each of the lower collectors was $1 \mathrm{~m}$ above the bottom. The position of the collectors was fixed and did not move up and down with changes in the tides.

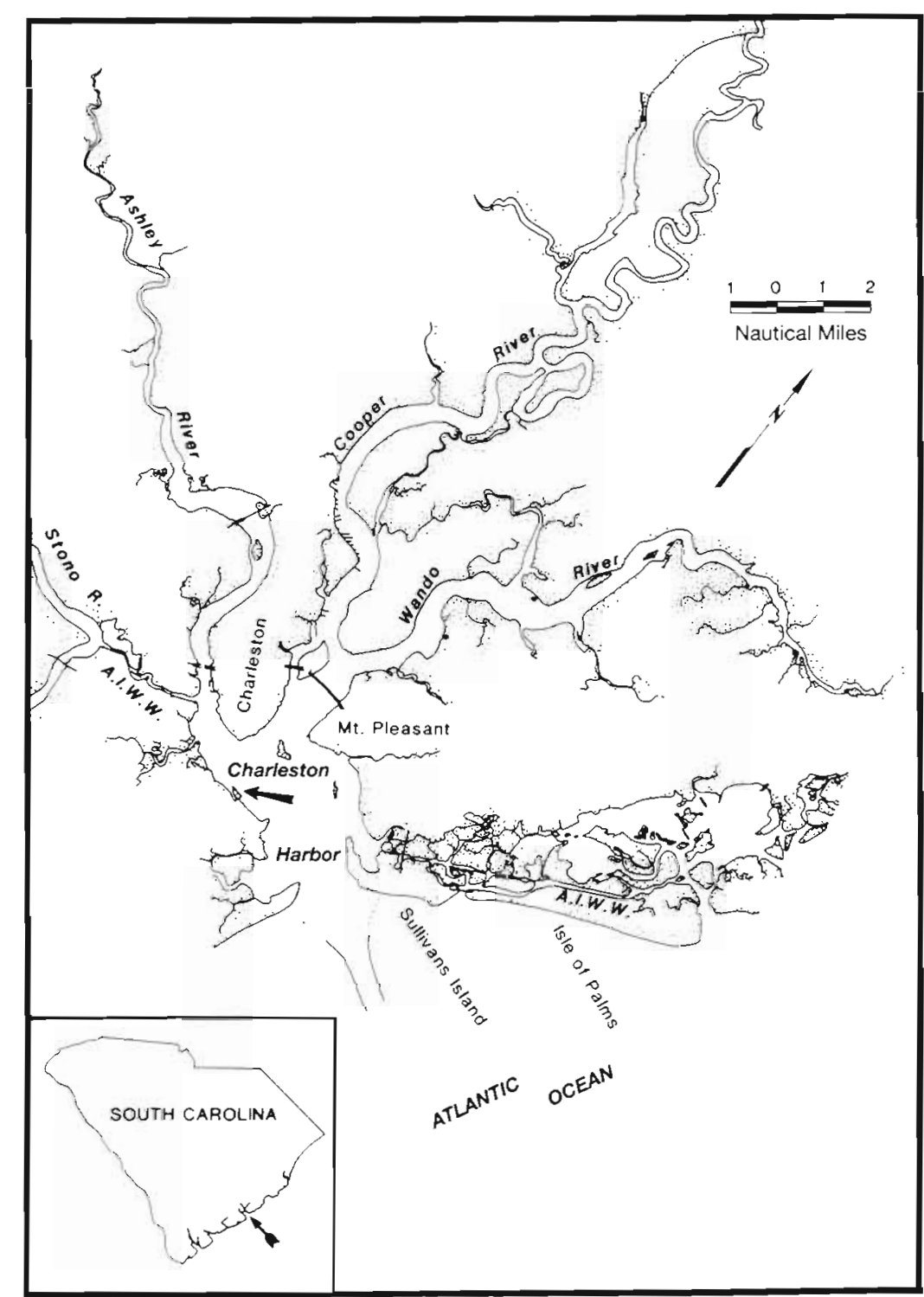

Fig. 1. Charleston Harbor, Charleston, South Carolina, USA, showing location of study site 
Upon retrieval, the collectors were rinsed with fresh water onto a $425 \mu \mathrm{m}$ mesh sieve for $10 \mathrm{~min}$. Each sample was preserved with $10 \%$ buffered formalin, sorted, and the brachyurans were removed, identified to the lowest taxonomic level possible, and enumerated. The megalopae of Callinectes sapidus were measured from the tip of the rostrum to the posterior edge of the carapace according to methods described by Mense \& Wenner (1989). Juvenile brachyurans were measured for carapace width, the distance across the posteriormost anterolateral spines. All measurements were made to the nearest $0.01 \mathrm{~mm}$ with an ocular micrometer in a dissecting microscope.

Physical measurements taken for each of the 1446 samples included salinity and temperature of surface and bottom water. Daily tidal height and vectoraveraged wind direction and speed records were provided by the National Oceanographic and Atmospheric Administration (NOAA).

Data analyses focused on characterizing variations in numbers of megalopae collected during different light phases (e.g. day vs night), seasons, and lunar phases. Lunar quarters were defined as: first or new moon (lunar days 1 to 7 ), second or waxing half moon (lunar days 8 to 14 ), third or full moon (lunar days 15 to 22) and fourth or waning half moon (lunar days 23 to 30 ). Pertinent analyses were repeated after the elimination of data from a settlement event of preponderate magnitude in order to avoid any misinterpretations due to skewed results. Data from daily and every-5-d collections were analyzed separately. Analyses may be assumed to have been performed on every-5-d data, except where noted. Prior to statistical analyses, homogeneity of variances was determined by $F_{\max }-$ tests. Data were typically heteroscedastic and nonparametric tests of significance were utilized (Sokal \& Rohlf 1981). Differences between treatments were considered to be significant at the $\alpha=0.05$ level. The Mann-Whitney test ( $U$-statistic), a non-parametric equivalent of the 2-sample $t$-test, was used to compare the number of megalopae between years using only every-5-d data. Contingency tables using the $G$ statistic were used to determine if settlement was independent of light phase and wind direction. The significance of associations between megalopal abundance and precipitation, bottom water salinity, bottom water temperature, wind speed, and tidal range was tested using Pearson product-moment correlation coefficients, whereas circular-linear correlation (Batchelet 1981) was used to test the significance of correlations between megalopal abundance and circular variates such as wind direction, Iunar day, and lunar phase. The Kruskal-Wallis test was used to test for significant differences in the number of megalopae per collector among seasons. The Kolmogorov-Smirnov 2-sample test was used to test for differences in the size distributions of blue crab megalopae from spring and fall collections.

\section{RESULTS}

\section{Megalopal abundance in relation to physical and meteorological data}

Salinities at the study site ranged from 8.6 to $31.5 \%$ $(\bar{x}=23.2 \%, \mathrm{SD}=3.7)$. Highest salinities were recorded in July and August 1988, while lowest values occurred in September 1987, after a period of heavy rainfall. Surface water temperatures varied from 5.3 to $28.0^{\circ} \mathrm{C}$ $(\bar{x}=22.3, \mathrm{SD}=4.2)$. Temperatures were generally below $10^{\circ} \mathrm{C}$ in January and February and above $20^{\circ} \mathrm{C}$ from May through October.

In daily collections the abundance of Callinectes sapidus megalopae was negatively correlated with tidal range $(\mathrm{r}=-0.275, \mathrm{p}<0.0001)$ and positively correlated with bottom water temperature $(\mathrm{r}=0.277, \mathrm{p}<$ $0.0001)$ and bottom water salinity $(\mathrm{r}=0.132, \mathrm{p}<0.05)$. Collections made every $5 \mathrm{~d}$ were also negatively correlated with tidal range $(\mathrm{r}=-0.113, \mathrm{p}<0.05)$. Although settlement was not uniformly distributed in relation to wind direction, no significant correlation was found. Wind speed, however, was found to correlate significantly with megalopal abundance of $C$. sapidus in daily collections ( $r=0.175, p<0.001)$. No significant correlation was noted for the relationship between number of megalopae and precipitation.

\section{Species composition}

A total of 31553 brachyuran megalopae, constituting 19 taxa, settled on the artificial substrates during the 15 mo study (Table 1). Settlement patterns were highly episodic: over 13000 megalopae (approximately $42 \%$ of the total number collected during the 15 mo study) were captured on a single day (August 19, 1987). None of the physical factors measured appeared to be related to this heavy settlement episode.

The most prevalent species, in both number and occurrence, was Callinectes sapidus, which constituted $79.2 \%$ of the total number of megalopae collected and was present in $44.8 \%$ of the collections. The period of major settlement by $C$. sapidus megalopae occurred from August through October in both 1987 and 1988 (Fig. 2), with settlement being significantly greater in 1987 ( $p<0.0015$, Mann-Whitney U-test). Postlarvae of C. sapidus were collected in all months except March, and only blue crab postlarvae were collected from mid-October 1987 to early April 1988. 
Table 1 Total number of megalopae of each brachyuran taxon collected from Charleston Harbor, in order of decreasing abundance. Percent of total number, frequency of occurrence, and percent occurrence in collections are also noted

\begin{tabular}{|lrrrr|}
\hline Species & $\begin{array}{c}\text { Total } \\
\text { number }\end{array}$ & $\begin{array}{c}\% \\
\text { Number }\end{array}$ & $\begin{array}{c}\text { Frequency } \\
\text { of occur. }\end{array}$ & $\begin{array}{c}\% \\
\text { Occur. }\end{array}$ \\
\cline { 1 - 1 } Megalopae & & & & \\
Callinectes sapidus & 25004 & 79.24 & 643 & 44.84 \\
Uca spp. & 2004 & 6.35 & 270 & 18.83 \\
Panopeus herbstii & 1862 & 5.90 & 322 & 22.45 \\
Hexapanopeus angustifrons & 916 & 2.90 & 86 & 6.00 \\
Neopanope sayi & 654 & 2.07 & 169 & 11.79 \\
Sesarma cinereum & 485 & 1.54 & 45 & 3.14 \\
Rhithropanopeus harrisii & 290 & 0.92 & 67 & 4.67 \\
Menippe mercenaria & 207 & 0.66 & 34 & 2.37 \\
Panopeus occidentalis & 28 & 0.09 & 10 & 0.70 \\
Hepatus epheliticus & 23 & 0.07 & 10 & 0.70 \\
Arenaeus cribranius & 16 & 0.05 & 10 & 0.70 \\
Eurypanopeus depressus & 16 & 0.05 & 9 & 0.63 \\
Ocypode quadrata & 14 & 0.04 & 10 & 0.70 \\
Libinia sp. & 12 & 0.03 & 7 & 0.49 \\
Callinectes similis & 11 & 0.03 & 11 & 0.77 \\
Pilumnus sp. & 6 & 0.02 & 4 & 0.28 \\
Epialtus dilatatus & 2 & 0.01 & 2 & 0.14 \\
Micropanope sp. & 2 & 0.01 & 2 & 0.14 \\
Pinnotheres sp. & 1 & 0.00 & 1 & 0.07 \\
Total & 31553 & & & \\
Juveniles & & & & \\
Arenaeus cribrarius & 118 & 38.2 & 35 & 70.00 \\
Callinectes similis & 70 & 22.6 & 41 & 82.00 \\
Callinectes sapidus & 66 & 21.4 & 42 & 84.00 \\
Portunus gibbesii & 49 & 15.9 & 14 & 28.00 \\
Ovalipes ocellatus & 6 & 1.9 & 6 & 12.00 \\
Total & 309 & & & \\
\hline
\end{tabular}

The mean length of blue crab megalopae captured during spring 1988 $(\bar{x}=2.32 \mathrm{~mm}, \mathrm{SE}=0.07)$ was greater than the size of those collected in late summer and fall $(\vec{x}=1.84 \mathrm{~mm}, \mathrm{SE}=0.09)$ of 1987 and 1988 (Fig. 3). The size distribution of blue crab megalopae collected in spring was significantly different from the distribution of those captured during fall $(p<$ $0.001, D=1.75$, Kolmogorov-Smirnov 2sample test), with those in spring being larger than the fall recruits.

Uca spp., which constituted $6.4 \%$ of the total number of megalopae, was the second most abundant taxon settling on the collectors (Table 1). This group ranked third in frequency of occurrence $(18.8 \%$ ). For Uca spp, there was a discrete period of settlement between mid-May and midOctober (Fig. 2). The third most numerically important species, Panopeus herbstii. constituted $5.9 \%$ of the total (Table 1). This mud crab was the second most frequently occurring species $(22.4 \%$ ) and was most abundant on the collectors from mid-May through mid-October (Fig. 2).

The remaining species made up less than $9 \%$ of the total (Table 1). Brachyuran megalopae were captured in all months except March. Relatively few megalopae were collected during spring and winter months. Although settlement by portunid megalopae, other than Callinectes sapidus, was low, recently metamorphosed portunid crabs did settle on the collectors (Table 1). The average carapace width of juveniles of all portunid species was $3.4 \mathrm{~mm}$, with the smallest specimen measuring $1.2 \mathrm{~mm}$ and the largest measuring $20.6 \mathrm{~mm}$. A total of 309 juvenile portunid crabs was collected, of which Arenaeus cribrarius was the most abundant species, constituting $38.2 \%$ of the crabs collected. Juveniles of $A$. cribrarius were collected from May through September, with peak abundance occurring in June, when $76.3 \%$ were collected. The portunids Callinectes similis and $C$. sapidus constituted 22.6 and $21.6 \%$, respectively, of the total number of juvenile crabs. The occurrence of juvenile C. sapidus on collectors was intermittent, occurring in February, May, July, August, September, and October. Peak abundance ( $60.6 \%$ of the total abundance) of $C$. sapidus juveniles occurred in October. Juvenile C. similis were collected from April through November with peak abundance in August and September. The juvenile portunids that were least abundant on collectors were Portunus gibbesii and Ovalipes ocellatus. No megalopae of these 2 species were collected during the 15 mo study.
Fig. 2. Total number of megalopae collected for each sampling date 


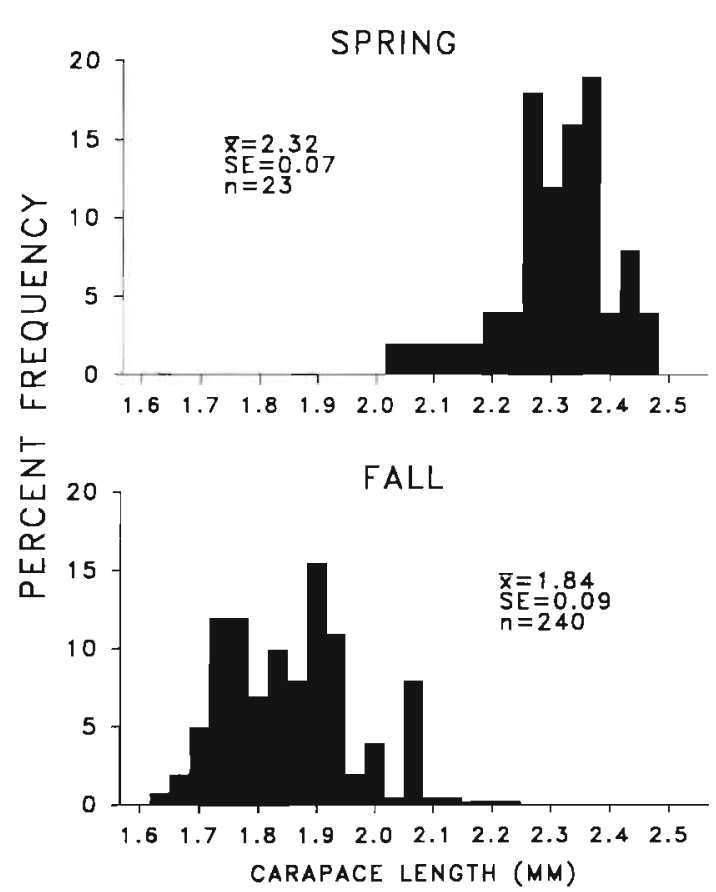

Fig. 3. Callinectes sapidus. Size-frequency histograms of megalopal carapace lengths from spring and fall 1988. Mean length $(\bar{x})$, standard error (SE), and number of megalopae (n) are given for each season

\section{Diel variation}

Comparisons of the numbers of megalopae collected at night and during the day revealed that megalopae were significantly ( $p<0.0001, G=10186, G$-test for Goodness of Fit) more numerous at night (Fig. 4). Day collections yielded 3840 megalopae, whereas 27713 were collected at night. All of the major taxa were significantly more abundant at night except Arenaeus cribrarius (Table 2). Of the 309 juvenile portunids collected, $47.2 \%$ appeared in day collections and $52.8 \%$ were collected at night.

\section{Lunar effects}

Settlement of megalopae differed significantly among lunar phases ( $p<0.0001, \chi^{2}=96.01$, KruskalWallis test), with greatest abundance occurring during the fourth lunar quarter. Forty-two percent of the total number of megalopae were collected on lunar day 26 in August 1987.

A bimodal peak in settlement was found for the period from September 25 to October 25, 1988, when daily samples were collected. Greatest numbers for that month were collected around lunar days 7 and 24 near half moons (Fig. 5). Mean settlement of megalopae per lunar day for all months showed a similar bimodal pattern of settlement (Fig. 5).

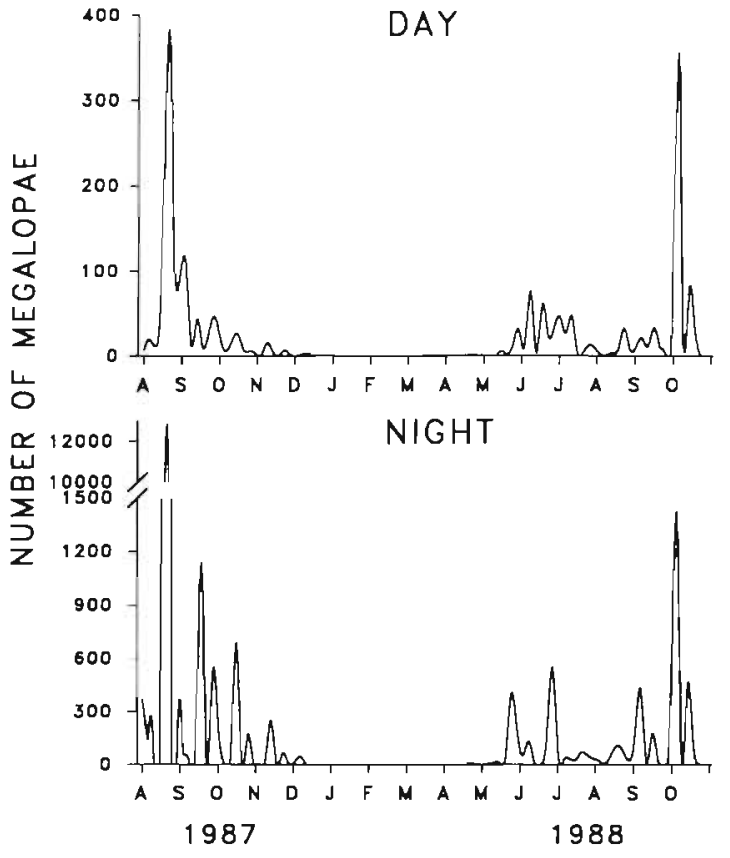

Fig. 4. Numbers of megalopae collected in day and night collections for each sampling date

Significant differences in the numbers of individuals among lunar phases were found for all numerically dominant species of megalopae, except Hexapanopeus angustifrons (Table 3). Lunar patterns of settlement were variable among these species,

Table 2. Comparison of the number of megalopae collected during different light phases. Species as in Table 1. A G-test for Goodness of Fit was conducted on numbers of megalopae taken in day/night comparison collections for each of the numerically dominant species

\begin{tabular}{|lrrrc|}
\hline Species & Day & Night & G-statistic & $p$ \\
\hline Megalopae & & & & \\
C. sapidus & 2795 & 22209 & 17148.8 & $<0.001$ \\
Uca spp. & 454 & 1550 & 633.6 & $<0.001$ \\
P. herbstii & 243 & 1619 & 1138.8 & $<0.001$ \\
H. angustifrons & 59 & 857 & 832.1 & $<0.001$ \\
N. sayi & 102 & 552 & 340.4 & $<0.001$ \\
S. cinereum & 10 & 475 & 574.9 & $<0.001$ \\
R. harrisii & 58 & 232 & 111.8 & $<0.001$ \\
M. mercenaria & 80 & 127 & 10.8 & $<0.005$ \\
P. occidentalis & 1 & 27 & 30.2 & $<0.001$ \\
H. epheliticus & 6 & 17 & 5.5 & $<0.025$ \\
A. cribrarius & 14 & 2 & 10.1 & $<0.005$ \\
E. depressus & 3 & 13 & 6.7 & $<0.01$ \\
O. quadrata & 2 & 12 & 7.9 & $<0.005$ \\
Juveniles & & & & \\
A. cribrarius & 64 & 54 & 0.8 & $<0.1$ \\
C. similis & 35 & 35 & 0.0 & $<0.9$ \\
C. sapidus & 4 & 62 & 61.3 & $<0.001$ \\
P. gibbesii & 43 & 6 & 31.5 & $<0.001$ \\
O. ocellatus & 0 & 6 & 8.3 & $<0.005$ \\
& & & & \\
\hline
\end{tabular}




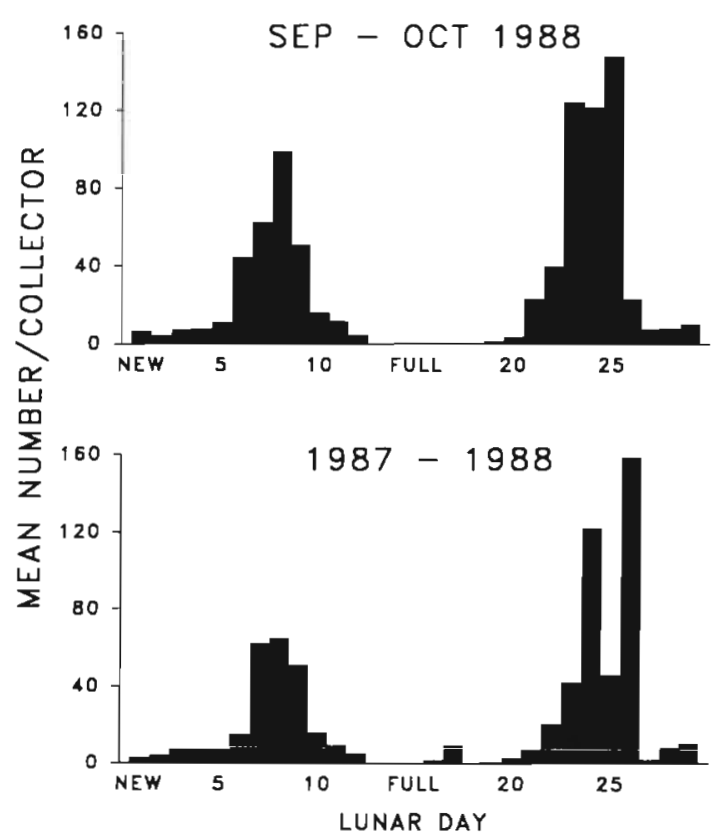

Fig. 5. Mean number of megalopae per collector per lunar day averaged from daily collections made in September and October of 1988 and from every-5-d collections

however. The observed bimodal pattern of brachyuran settlement was largely due to the settlement patterns of blue crab larvae (Fig. 6). The megalopae of Callinectes sapidus were most numerous during the fourth lunar quarter and least abundant during the third lunar quarter. Settlement of blue crab megalopae was positively correlated with lunar day $(U=8.09, \mathrm{p}<0.05)$ and lunar phase $(U=6.08, \mathrm{p}<$ 0.01). A similar lunar periodicity in settlement was found for juvenile $C$. sapidus, but not for the juveniles of other portunids.

Settlement of Uca spp. megalopae was greatest during the fourth lunar quarter, whereas settlement of Panopeus herbstii was highest during the second lunar quarter, with a somewhat smaller peak during the fourth (Fig. 6).

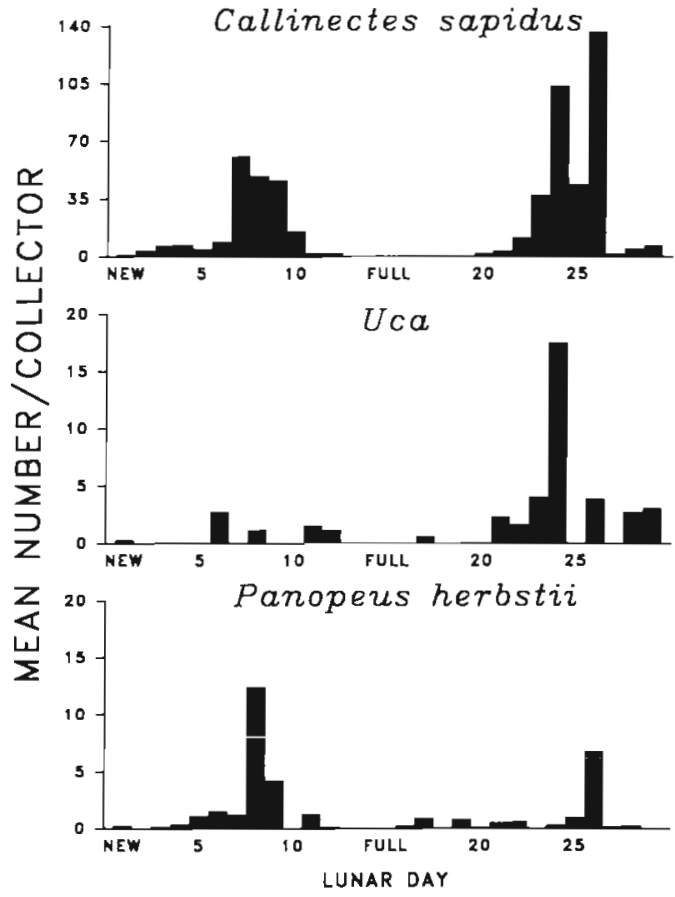

Fig. 6. Mean number of megalopae per collector per lunar day for Callinectes sapidus, Uca spp., and Panopeus herbstii

\section{DISCUSSION}

\section{Temporal patterns of abundance}

The 19 brachyuran taxa that were collected during the study commonly occur in the Charleston Harbor estuarine system as adults (Wenner et al. 1984). In the present study the 3 taxa that dominated collections, Callinectes sapidus, UCa spp., and Panopeus herbstii, constituted over $91 \%$ of the megalopae collected during the 15 mo study. Numerical abundance of taxa varied greatly among replicate samples, suggesting small-scale spatial patchiness, and among sampling dates, suggesting a temporally variable distribution. Spawning patterns of adults, larval transport processes,

Table 3. Mean number of megalopae captured per collector during different lunar phases with results of a Kruskal-Wallis test showing significance of differences in abundance. Lunar quarters were defined as follows - First: lunar days 1 to $7 ;$ Second

lunar days 8 to 14; Third: lunar days 15 to 22 i and Fourth: lunar days 23 to 30. Data from August 19, 1987 were excluded

\begin{tabular}{|c|c|c|c|c|c|c|}
\hline \multirow[t]{2}{*}{ Species } & \multicolumn{4}{|c|}{ Lunar phase } & \multirow[t]{2}{*}{$x^{2}$} & \multirow[t]{2}{*}{$\mathrm{p}$} \\
\hline & $\begin{array}{c}\text { First } \\
(\mathrm{n}=426)\end{array}$ & $\begin{array}{l}\text { Second } \\
(n=276)\end{array}$ & $\begin{array}{c}\text { Third } \\
(\mathrm{n}=468)\end{array}$ & $\begin{array}{l}\text { Fourth } \\
(\mathrm{n}=276)\end{array}$ & & \\
\hline Callinectes sapidus & 6.84 & 8.78 & 2.18 & 25.61 & 86.53 & $<0.0001$ \\
\hline Uca spp. & 1.26 & 1.22 & 0.71 & 2.15 & 8.24 & $<0.05$ \\
\hline Panopeus herbstij & 0.88 & 2.12 & 0.36 & 1.37 & 35.85 & $<0.0001$ \\
\hline Hexapanopeus angustifrons & 0.20 & 1.17 & 0.11 & 0.06 & 6.67 & $<0.08$ \\
\hline Neopanope sayi & 0.37 & 0.70 & 0.24 & 0.45 & 10.89 & $<0.01$ \\
\hline Sesarme cinereum & 0.06 & 0.13 & 0.06 & 0.63 & 12.24 & $<0.01$ \\
\hline
\end{tabular}


and the physiology and behavior of potential recruits probably all contributed to the observed temporal patterns (Olmi et al. 1990). The species composition and numerical abundance of settling megalopae do not necessarily reflect planktonic availability, however, due to possible differences in thigmotactic responses among taxa.

Although Callinectes sapidus megalopae are reportedly eurythermal with settlement occurring during much of the year (van Montfrans et al. 1990), the major settlement period of blue crab megalopae at the study site occurred during late summer and early fall, similar to the timing of ingress to tidal creeks in South Carolina (Olmi 1986, Mense \& Wenner 1989). Orth \& van Montfrans (1987) suggested that the new year-class of C. sapidus enters grassbed and marsh creek habitats in the lower Chesapeake Bay during this time. In South Carolina waters, peak mating activity and spawning have been reported to occur in April (Eldridge \& Waltz 1977). Archambault et al. (1990) found that the spawning period of $C$. sapidus in Charleston Harbor extends from March to November. Since the time interval between spawning (egg extrusion) and the megalopal stage of development varies from 42 to $60 \mathrm{~d}$ under constant conditions in the laboratory for $C$. sapidus (Churchill 1921, Costlow 1967, Bookhout \& Costlow 1975), one would expect peak megalopal abundance to occur in June or July in South Carolina if peak spawning were occurring in April. Mense \& Wenner (1989) suggested that peak spawning of $C$. sapidus occurs in the summer, rather than in spring, a premise which seems to be supported by our findings

Blue crab megalopae collected in the spring were significantly larger and exhibited a significantly different size distribution than those from fall collections. From this, we conclude that 2 cohorts of blue crab megalopae exist in South Carolina. These results confirm earlier findings by Mense (1988), which showed that Callinectes sapidus immigrating to the Charleston Harbor system in the spring were significantly larger than those captured in fall months. Stuck \& Perry (1982) also found megalopae and first crabs of $C$. sapidus to be significantly larger in the spring in the Gulf of Mexico. Factors which influence these seasonal size variations have not yet been determined, but temperature was not found to have a significant effect on seasonal variations in size (Stuck \& Perry 1982). Rather, Stuck \& Perry (1982) suggested that seasonal size differences were related to food availability rather than temperature. If starvation occurs, blue crab larvae can suspend the molt cycle at premolt and reinitiate it when food becomes available (McConaugha 1985), perhaps resulting in larval or postlarval intermediates. Prolongation of the larval life of $C$. sapidus in late winter may result in a larger postlarva in the spring.
In the present study, juvenile blue crabs constituted less than $0.3 \%$ of the total number of Callinectes sapidus collected. The recruitment of blue crabs in South Carolina has been found to occur at both megalopal and juvenile stages (Mense \& Wenner 1989, Olmi \& Sandifer 1990). Early studies suggested that ingress occurred at the juvenile stage (Tagatz 1968, Dudley \& Judy 1971). Mense \& Wenner (1989), however, found that numbers of juvenile blue crabs were low in plankton samples taken in estuarine habitats near Charleston Harbor, leading them to conclude that ingress into estuaries occurs at the megalopal stage. Blue crab recruitment to open salt marshes in South Carolina has been found to be by megalopae, whereas recruitment to nearby impoundments was by juvenile crabs (Olmi \& Sandifer 1990). In the Chesapeake Bay, high densities of blue crab megalopae were found at the mouth of the bay, but not elsewhere in the estuary, which suggests that the role of juvenile instars may be significant in that system (McConaugha 1988).

The postlarvae of portunids that live in coastal waters, Arenaeus cribrarius, Callinectes similis, Portunus gibbesii, and Ovalipes ocellatus, metamorphose into juvenile instars at higher salinities than do most estuarine brachyurans (Williams 1984). Our data indicate that recruitment of these species to the Charleston Harbor system is accomplished totally or, in part, by juveniles rather than solely by megalopae. Their seasonality in occurrence and abundance corresponds to the seasonal spawning cycles of the respective species (Williams 1984, Archambault et al. 1990).

The ingress of $U$ ca spp., which began in late spring and ended abruptly in October, corresponds with the known breeding seasons of UCa pugilator, U. minax, and $U$. pugnax in South Carolina (Christy 1982). Furthermore, megalopae of Panopeus herbstii demonstrated a similar seasonal pattern of settlement which overlaps their spawning season of late spring through late summer in the Carolinas (Williams 1984). Van Montfrans et al. (1990) noted a similar pattern for these species and suggested that termination of settlement in fall is regulated by a decrease in water temperature at about $15^{\circ} \mathrm{C}$, although the timing of spawning in conjunction with developmental times may also be influential factors. Less than $3 \%$ of the brachyuran postlarvae were collected in our study at water temperatures below $16^{\circ} \mathrm{C}$.

\section{Meteorological, diel and lunar effects}

Larval transport of blue crabs has been highly correlated with wind events (Hester 1983). Both wind direction and inner continental shelf circulation have been determined to be important factors affecting the ingress 
of larvae to estuaries in the Middle Atlantic Bight (Boicourt 1982); however, no significant correlation was found for the relationship between megalopal abundance and wind direction. Recent studies suggest a prominent role for intermittent wind-driven transport of surface waters in larval recruitment (Johnson 1985, Goodrich et al. 1989). Such a mechanism could possibly account for the episodic nature of megalopal settlement found in the current study, since wind speed was found to correlate significantly with the megalopal abundance of Callinectes sapidus and Uca spp., whose larvae develop offshore. The settlement event of August 19, 1987 coincided with southerly winds preceded by several days of winds out of the northeast, conditions which have been found to favor the concentration and transport of large numbers of larvae (Jack Blanton pers. comm.).

Megalopae of Callinertes sapidus exhibited lunarrelated periodicity in settlement, with the greatest settlement occurring on or around waning quarter moons and a secondary peak upon approach of the waxing quarter moon. This pattern differs from that found by van Montfrans et al. (1990), who studied the settlement of megalopae on collectors in the York River, Virginia, USA. They found settlement to be higher around the full moon, whereas in the present study the lowest settlement was found to occur on or around the full moon. Although the reason for this discrepancy is unclear, greater tidal volume and flow in South Carolina estuaries around full moon could impede attachment of megalopae to the collectors, or the reason could be that the collectors in the Virginia study were not as close to the mouth of the estuary as were those in Charleston Harbor. In the current study, lunar day, lunar phase, and tidal range were significantly correlated with settlement. Peak settlement tended to occur shortly after the spring tides with greater settlement around the apogee spring tide.

The bimodal pattern of settlement of Callinectes sapidus observed in this study may be related to shoreward transport of megalopae by tides; however, this pattern also suggests synchronous behavior related to lunar phase. Van Montfrans et al. (1990) suggested that megalopae of C. sapidus may molt synchronously in relation to lunar phase beginning at the megalopal stage, and they further suggested that such behavior would provide some degree of protection from predation. The semilunar pattern of settlement of Panopeus herbstii was similar to that of $C$. sapidus. Although the present study showed a weak semilunar pattern for megalopae of Uca spp., the bimodal pattern of $U_{C a}$ settlement found by Christy (1982) in the North Inlet estuary, South Carolina, was more pronounced. This may be a reflection of differences in the physical characteristics of the 2 study areas.
The significantly greater number of megalopae collected at night is similar to other observations made in estuaries of South Carolina. This may be attributed to rapid transport of postlarvae on nocturnal flood currents (Christy 1989). In the North Inlet estuary, South Carolina, Christy (1982) found significantly more megalopae of Uca spp. in the water column at night. Mense \& Wenner (1989), in a study of the distribution and abundance of blue crab megalopae and early crab stages in estuarine habitats near Charleston Harbor, found significantly higher abundances of blue crab megalopae in night collections and hypothesized that vertical distribution was related to light phase based on greater abundances in daylight bottom collections and in night surface samples. Although laboratory studies have shown that light is not an important cue for vertical orientation related to vertical migration in estuaries due to their higher turbidity (Forward \& Cronin 1978, Sulkin 1984), it is clear that light plays an important role in the settlement of blue crab megalopae. Vertical migration cued by tidal phase has been suggested for Callinectes sapidus in vertically mixed estuaries (Epifanio et al. 1984, Epifanio 1988). Any future studies of megalopae in estuarine systems along the South Atlantic Bight should be designed to relate settlement to both light and tidal phases as well as to examine the spatial variability of megalopae both in estuarine systems and in nearshore areas.

Acknowiedgements. The authors thank C. K. Biernbaum, P. A. Sandifer, and D. M. Knott for their comments on an earlier draft of the manuscript. They are grateful to J. Escobar for his assistance in sampling, M. J. Clise for her help with data management, and K. R. Swanson for her help with graphics. Financial support for this study was provided by the South Carolina Sea Grant Consortium and the Slocum-Lunz Foundation.

\section{LITERATURE CITED}

Archambault, J. A., Wenner, E. L., Whitaker, J. D. (1990). Life history and abundance of blue crab, Callinectes sapidus Rathbun, at Charleston Harbor, South Carolina. Bull. mar. Sci. 46: 145-158

Batchelet, E. (1981). Circular statistics in biology. Academic Press, New York

Beninger, P. G., Chiasson, L., Elner, R. W. (1986). The utility of artificial collectors as a technique to study benthic settlement and early juvenile growth of the rock crab, Cancer irroratus. Fish. Res. 4: 317-329

Boicourt, W. C. (1982). Estuarine larval retention mechanisms on two scales. In: Kennedy, V. S. (ed.) Estuarine comparisons. Academic Press, New York, p. 445-457

Bookhout, C. G., Costlow, J. D. Jr (1975). Effects of mirex on the larval development of blue crab. Wat. Air Soil Pollut. 4: $113-126$

Botsford, L. W., Shenker, J. M. (1988). Possible influence of wind on Cancer magister settlement. J. Shellfish Res. 7: 111 
Christmas, J. Y, van Devender, T N. (1981). Prediction of shrimp landings from investigations on the abundance of post-larval shrimp. Kuwait Bull. mar. Sci. 2: 301-310

Christy, J. H. (1982). Adaptive significance of semilunar cycles of larval release in fiddler crabs (genus $U c a$ ): test of an hypothesis. Biol. Bull. 163: 251-263

Christy, J. H. (1989). Rapid development of megalopae of the fiddler crab Uca pugilator reared over sediment: implications for models of larval recruitment. Mar Ecol. Prog. Ser. 57: 259-265

Churchill, E. P. Jr (1921). Life history of the blue crab. Bull. U.S. Bur. Fish. 36: 95-128

Costlow, J. D. (1967). The effect of salinity and temperature on survival and metamorphosis of the blue crab, Callinectes sapidus Rathbun. Helgoländer wiss. Meeresunters. 15: $84-97$

Davis, K. B., Anderson, G. S., Durel, A. M. (1990). Hydrography. In: Van Dolah, R. F., Wendt, P. H., Wenner, E. L. (eds.) A physical and ecological characterization of the Charleston Harbor estuarine system. Final Report to South Carolina Coastal Council, Charleston, p. 11-46

Dudley, D. L., Judy, M. H. (1971). Occurrence of larval, juvenile and mature crabs in the vicinity of Beaufort Inlet, North Carolina. NOAA Tech. Rep., NMFS, SSRF 637

Eldridge, P. J., Waltz, W. (1977). Observations on the commercial fishery for blue crabs, Callinectes sapidus, in estuaries in the southern half of South Carolina. South Carolina Marine Resources Center, Tech. Rep. No. 21

Epifanio, C. E. (1988). Transport of invertebrate larvae between estuaries and the continental shelf. Am. Fish. Soc. Symp.: 104-114

Epifanio, C. E., Valenti, C. C., Pembroke, A. E. (1984). Dispersal and recruitment of blue crab larvae in the Delaware Bay, USA. Estuar. coast. Shelf Sci. 18: 1-12

Forward, R. B. Jr, Cronin, T. W. (1978). Crustacean larval phototaxis: possible significance. In: McLusky, O. S., Berry, A. J. (eds.) Physiology and behavior of marine organisms. 12th Eur. Symp. Mar. Biol. Pergamon Press, Oxford, p. 253-261

Goodrich, D. M., van Montfrans, J., Orth, R. J. (1989). Blue crab megalopal influx to Chesapeake Bay: evidence for a wind-driven mechanism. Estuar. coast. Shelf Sci. 29: $247-260$

Hester, B. S. (1983). A model of the population dynamics of the blue crab in Chesapeake Bay. Ph.D. dissertation, Old Dominion University, Norfolk, VA

Johnson, D. F., Botsford, L. W., Methot, R. D. Jr, Wainwright, T C. (1986). Wind stress and cycles in Dungeness crab (Cancer magister) catch off California, Oregon, and Washington. Can. J. Fish. Aquat. Sci. 43: 838-845

Johnson, D. R. (1985). Wind-forced dispersion of blue crab larvae in the Middle Atlantic Bight. Cont. Shelf Res. 6: $733-745$

Johnson, D. R., Hester, B. S., McConaugha, J. R. (1984) Studies of a wind mechanism influencing the recruitment of blue crabs in the Middle Atlantic Bight. Cont. Shelf Res. 3: 425-437

Kjerfve, B., Magill, K. E., Sojisuporn, P. (1990). Physical dynamics. In: Van Dolah, R. F., Wendt, P. H., Wenner, E. L. (eds.) A physical and ecological characterization of the Charleston Harbor estuarine system. Final Report to South Carolina Coastal Council, Charleston, p. 99-120

Little, E. J. Jr, Milano, G. R. (1980). Techniques to monitor recruitment of postlarval spiny lobsters, Panulirus argus, to the Florida Keys. Fla mar. Res. Publ. 37

Mathews, T D., Shealy, M. H. Jr (1978). Hydrography of South Carolina estuaries, with emphasis on the North and
South Edisto and Cooper Rivers. South Carolina Marine Resources Center, Tech. Rep. 30

McConaugha, J. R. (1985). Nutrition and growth. In: Wenner A. M. (ed.) Larval growth. Crustacean issues, Vol. 2. A. A. Balkema, Boston, p. 127-154

McConaugha, J. R. (1988). Export and reinvasion of larvae as regulators of estuarine decapod populations. Am. Fish Soc. Symp. 3: 90-103

Mense, D. J. (1988). Densities of megalopae and early crab stages of the blue crab, Callinectes sapidus, in shallow estuarine habitats near Charleston Harbor. Master's thesis, College of Charleston, Charleston, SC

Mense, D. J., Wenner, E. L. (1989). Distribution and abundance of early life history stages of the blue $\mathrm{crab}^{\mathrm{C}} \mathrm{Cal}$ linectes sapidus, in tidal marsh creeks near Charleston, S.C. Estuaries 12: $157-168$

Morgan, G. R., Phillips, B. F., Joll, L. M. (1982). Stock and recruitment relationships in Panulirus cygnus, the commercial rock (spiny) lobster of Western Australia. Fish Bull. U.S. 80: $475-486$

National Oceanographic and Atmospheric Administration. (1985). National estuarine survey - data atlas - Volume I Physical and hydrologic characteristics. United States Department of Commerce, NOAA, Washington, DC

Olmi, E. J. III. (1986). Recruitment patterns of selected decapod crustaceans. In: Devoe, M. R., Baughman, D. S. (eds.) South Carolina coastal impoundments: ecological characterization, management, status, and use, Vol 2. South Carolina Sea Grant Consortium, Publ. No. SC-SG-TR-86-2, Charleston, p. 303-360

Olmi, E. J., Sandifer, P. A. (1990). Recruitment of blue crab, Callinectes sapidus, in open and impounded marsh systems in South Carolina. J. Shellfish Res. 7: 128

Olmi, E. J. III, van Montfrans, J., Lipcius, R. N., Orth, R. J., Sadler, P. W. (1990). Variation in planktonic variability and settlement of blue crab megalopae in the York River, Virginia. Bull. mar. Sci. 46: 230-243

Orth, R. J., van Montfrans, J. (1987). Utilization of a seagrass meadow and tidal marsh creek by blue crabs, Callinectes sapidus. I. Seasonal and annual variations in abundance with emphasis on post-settlement juveniles. Mar. Ecol. Prog. Ser. 41: 283-294

Phillips, B. F. (1972). A semi-quantitative collector of the puerulus larvae of the western rock lobster, Panulirus longipes cygnus George (Decapoda, Palinuridae). Crustaceana 22: $147-154$

Phillips, B. F. (1986). Prediction of commercial catches of the western rock lobster, Panulirus cygnus. Can. J. Fish. Aquat. Sci. 43: 2126-2130

Roughgarden, J., Gaines, S., Possingham, H. (1988). Recruitment dynamics in complex life cycles. Science 241 : 1460-1466

Serfling, S. A., Ford, R. F. (1975). Ecological studies of the puerulus larval stage of the California spiny lobster, Panulirus interruptus. Fish. Bull. U.S. 73(2): 360-377

Shanks, A. L. (1983). Surface slicks associated with tidal forced internal waves may transport pelagic larvae of benthic invertebrates and fishes shoreward. Mar. Ecol. Prog. Ser. 13 (2-3): 311-315

Shanks, A. L. (1988). Further support for the hypothesis that internal waves can cause shoreward transport of larval invertebrates and fish. Fish Bull. U.S. 86: 703-714

Sokal, R. R., Rohlf, F. J. (1981). Biometry. W. H. Freeman and Co., New York

Stuck, K. C., Perry, H. M. (1982). Morphological characteristics of blue crab larvae, Callinectes sapidus Rathbun, from 
the northern Gulf of Mexico. Gulf States Marine Fisheries Commission, Tech. Rep. 011

Sulkin, S. D. (1984). Behavioral basis of depth regulation in the larvae of brachyuran crabs. Mar. Ecol. Prog. Ser. 15: $181-205$

Sulkin, S. D., Epifanio, C. E. (1986). Natural regulation of juvenile recruitment in the blue crab (Callinectes sapidus Rathbun) and its consequences for sampling and management strategy. Can. Spec. Publ. Fish. Aquat. Sci. 92: $117-123$

Tagatz, M. E. (1968). Biology of the blue crab, Callinectes sapidus Rathbun, in the St. Johns River, Florida. Fish. Bull. U.S. 67 : $17-33$

van Montfrans, J., Peery, C. A., Orth, R. J. (1990). Daily, monthly, and annual settlement patterns by Callinectes

This article was presented by K. L. Heck, Dauphin Island, Alabama, USA sapidus and Neopanope sayi megalopae on artificial collectors deployed in the York River, Virginia. Bull. mar. Sci. 46: 214-228

Wenner, E. L., Coon, W. P. III, Shealy, M. H. Jr, Sandifer, P. A (1984). A five-year study of seasonal distribution and abundance of fishes and decapod crustaceans in the Cooper River and Charleston Harbor, S.C., prior to diversion. NOAA Tech. Rep. NMFS SSRF-782

Williams, A. B. (1984). Shrimps, lobsters, and crabs of the Atlantic coast of the eastern United States, Maine to Florida. Smithsonian Institutional Press, Washington, DC

Withham, R., Ingle, R. M., Joyce, E. A. Ji (1968). Physiological and ecological studies of Panulirus argus from the St. Lucie Estuary. Fla Bd Conserv., Tech. Ser. No. 53

Manuscript first received: September 15, 1991 Revised version accepted: April 27, 1993 